九州大学学術情報リポジトリ

Kyushu University Institutional Repository

\title{
Freezing Tolerance of Lactuca sativa and Induction of CBF and GolS Genes during Cold Treatment
}

HONJOH, Ken-ichi

Laboratory of Food Hygienic Chemistry, Division of Food Science and Biotechnology, Department of Bioscience and Biotechnology, Faculty of Agriculture, Kyushu University

OKANO, Hitomi

Laboratory of Food Hygienic Chemistry, Division of Food Science and Biotechnology, Department of Bioscience and Biotechnology, Faculty of Agriculture, Kyushu University

KAWABATA, Aya

Laboratory of Food Hygienic Chemistry, Division of Food Science and Biotechnology, Department of Bioscience and Biotechnology, Faculty of Agriculture, Kyushu University

\section{KUROKAWA, Masaru}

Laboratory of Food Hygienic Chemistry, Division of Food Science and Biotechnology, Department of Bioscience and Biotechnology, Faculty of Agriculture, Kyushu University

他

https://doi.org/10.5109/1955390

出版情報：九州大学大学院農学研究院紀要. 63 (2)，pp.249-257，2018-09-01. Faculty of Agriculture, Kyushu University

バージョン :

権利関係 : 


\title{
Freezing Tolerance of Lactuca sativa and Induction of $C B F$ and GolS Genes during Cold Treatment
}

\section{Ken-ichi HONJOH*, Hitomi OKANO ${ }^{1}$, Aya KAWABATA ${ }^{1}$, Masaru KUROKAWA', Taiki KIMURA ${ }^{1}$, Takeshi MACHIDA², Yoshimitsu MASUDA and Takahisa MIYAMOTO}

\author{
Laboratory of Food Hygienic Chemistry, Division of Food Science and Biotechnology, \\ Department of Bioscience and Biotechnology, Faculty of Agriculture, \\ Kyushu University, Fukuoka 812-8581, Japan \\ (Received May 1, 2018 and accepted May 8, 2018)
}

\begin{abstract}
Plants respond to several environmental changes such as low- and high-temperatures, drought, flood, and so on, leading to development of stress tolerance. Acquisition abilities of freezing tolerance of three lettuce cultivars were investigated. All the investigated cultivars showed improvement of freezing tolerance at $-3^{\circ} \mathrm{C}$ after exposure to non-freezing low-temperature at $2^{\circ} \mathrm{C}$ for 7 days. Out of them, papa lettuce cultivar was used to investigate expression levels of cold-responsive genes. The cultivar showed induction of $C B F$ and GolS genes, which are well known as cold-responsive genes in other plants, during cold treatment. These results showed that lettuce has at least one cold-responsive signal pathway, suggesting a possibility that genetical modification might enhance the freezing tolerance.
\end{abstract}

Key words: C-repeat/DRE binding factor, freezing tolerance, galactinol synthase, lettuce

\section{INTRODUCTION}

Extreme weather events such as drought, flooding, typhoon, cold summer, and so on have threatened the stable production and the supply of agricultural produce such as crops and vegetables. Although lettuce is one of important produces and is affected by extreme weather events, there are not many reports concerning its response to environmental changes such as abiotic stress. Several researchers reported responses of lettuce to drought or salt stress (Garrido et al., 2013; Leyva et al., 2011; Porcel et al., 2005; Ruiz-Lozano et al., 1996), however there are few reports concerning responses of lettuce to cold stress.

From a model plant, Arabidopsis thaliana, one cDNA clone corresponding to a gene encoding coldinducible transcriptional activator was isolated (Stockinger et al., 1997). Now, the activator is well known as a protein binding to a cis-acting DNA regulatory element, C-repeat/dehydration responsive element (DRE), in plants and the protein stimulates expression of genes responsible for enhancement of drought tolerance or freezing tolerance of the plants. The activator protein was called as the C-repeat/DRE binding factor $(\mathrm{CBF})$ and the homologous genes have been cloned from several plants. Introduction of a $C B F$ gene from Arabidopsis into Brassica napus led to expression of the genes induced by CBF proteins and enhancement of freezing tolerance of the plant, showing the existence of

Laboratory of Food Hygienic Chemistry, Division of Food Science and Biotechnology, Department of Bioscience and Biotechnology, Graduate School of Bioresource and Bioenvironmental Sciences, Kyushu University, Fukuoka 8128581, Japan

${ }^{2}$ Department of Immunology, School of Medicine, Fukushima Medical University, Fukushima 960-1295, Japan

* Corresponding author (E-mail: honjoh@agr.kyushu-u.ac.jp) cold-responsive pathways in B. napus (Jaglo et al., 2001). Although there are many reports concerning freezing tolerance or cold response of several plants such as Arabidopsis, there are few reports concerning cold response of plants such as lettuce which is not strong. If freezing tolerance of lettuce is improved, lettuce can be kept at lower temperatures than normal refrigerated temperature for storage. Thus, not only lettuce plants can acclimate to a rapid decline in temperature during cultivation, but also postharvest-storage period of lettuce is expected to be prolonged. In order to improve the freezing tolerance of lettuce plant, it is important to know the molecular response of the plant exposed to cold.

Arabidopsis overexpressing CBF3/DREB1A transcriptional factor accumulated raffinose and enhancement of freezing tolerance (Gilmour et al., 2000). Raffinose family oligosaccharides (RFO) including galactinol and raffinose are well studied as protectants against abiotic stress such as drought, salinity, cold stress in plant cells (Taji et al., 2002). For accumulation of galactinol and raffinose in plants, galactinol synthase catalyzes a first reaction for biosynthesis of RFO (Taji et al., 2002). Introduction of cold-inducible galactinol synthase gene from Medicago sativa into tobacco plant enhanced multiple tolerance of the plant to abiotic stresses (Zhuo et al., 2013).

In the present paper, we investigated freezing tolerance of three lettuce cultivars. From one of three cultivars, partial cDNA clones corresponding to $C B F$ and GolS genes were isolated. Then, expression patterns of the genes during cold treatment of lettuce plants were investigated.

\section{MATERIALS AND METHODS}

Plant materials and growth conditions

Seeds of three kinds of Lactuca sativa L. (Papa let- 
tuce, Mama lettuce, and Berkley) were obtained from Nakahara Seeds Co. Ltd. (Fukuoka, Japan). The seeds were disinfected with $70 \%$ ethanol for $10-15$ s, and then dipped in $0.2 \%$ sodium hypochlorite solution for $10 \mathrm{~min}$. The seeds were then rinsed three times with sterile water. The seeds were sown in pots $(7.5 \mathrm{~cm}$ diameter) with soil and lettuce plants were cultivated in a growth chamber (model MLR-350; SANYO, Co. Ltd., Tokyo, Japan) at $22^{\circ} \mathrm{C}$ under a photosynthetic photon flux density of about $40 \mu \mathrm{mol} / \mathrm{m}^{2} \mathrm{~s}$ with a $16 \mathrm{~h}$ photoperiod. Sterilized tap water was poured to the soil 2-3 day intervals.

\section{Cold treatment}

Lettuce plants grown for 2 weeks were incubated in a refrigerator (model SPR-T1281; SANYO) at $2{ }^{\circ} \mathrm{C}$ for indicated period. After this treatment, lettuce plants were used for following freezing treatment or harvested for preparation of total RNA. Harvested leaves were immediately frozen in liquid nitrogen and stored at $-80^{\circ} \mathrm{C}$ until preparation of RNA.

\section{Freezing test}

Low-temperature-treated or non-treated lettuce plants were moved into incubator and kept at $-3^{\circ} \mathrm{C}$ for 30 min. Then, crashed ice, which had been pre-incubated at $-3^{\circ} \mathrm{C}$, covered soil of the plant pot for ice nucleation. The lettuce plants were kept at $-3^{\circ} \mathrm{C}$ for $24 \mathrm{~h}$. For thawing, the frozen plants were moved to refrigerator and kept at $2{ }^{\circ} \mathrm{C}$ for further $24 \mathrm{~h}$. And then, the plants were moved to normal growth conditions at $22^{\circ} \mathrm{C}$ and further cultivated for a week to evaluate freezing tolerance. For evaluation of freezing tolerance, 5-7 lettuce plants were cultivated in a pot. Three pots were used for each experimental data point and four independent experiments were done. Viability was determined by expressing the number of plants, which survived after one week of freezing-thawing, as a percentage of number of plants subjected to freezing test.

\section{Preparation of total RNA}

For preparation of total RNA, a several leaves were harvested. The harvested leaves were grounded in liquid nitrogen using mortar and pestle until the leaves became power. Total RNA of lettuce leaves was prepared from this grounded powder using RNeasy Plant Mini Kit (QIAGEN, Tokyo, Japan) according to the manufacturer's instructions.

\section{Preparation of poly $(A)^{+}$RNA}

Poly (A) ${ }^{+}$RNA was purified from total RNA using Oligotex $^{\mathrm{TM}}$-dT30<Super $>$ mRNA Purification Kit (Takara, Kyoto, Japan), according to the manufacturer's instruction. The purified poly $(\mathrm{A})^{+} \mathrm{RNA}$ was dissolved in RNasefree water and the concentration of RNA solution was adjusted to $0.5 \mu \mathrm{g} / \mu \mathrm{l}$.

\section{Synthesis of first strand cDNA}

SMART Scribe ${ }^{\mathrm{TM}}$ Reverse Transcriptase (Clontech, Mountain View, CA, USA) was used for cDNA synthesis. At first, a mixture of $2 \mu \mathrm{l}$ of total RNA or poly $(\mathrm{A})^{+} \mathrm{RNA}$, $0.5 \mu \mathrm{l}$ of oligo $(\mathrm{dT})$ primer, and $2.5 \mu \mathrm{l}$ water was heated at $72{ }^{\circ} \mathrm{C}$ for $4 \mathrm{~min}$ in order to denature the RNA conformation. After cooling on ice, $2 \mu \mathrm{l}$ of $5 \times$ First-Strand buffer, $1 \mu \mathrm{l}$ of $10 \mathrm{mM}$ dNTP, $1 \mu \mathrm{l}$ of $20 \mathrm{mM}$ DTT, and $1 \mu \mathrm{l}$ of $100 \mathrm{U} / \mu \mathrm{l}$ of SMART Transcriptase RT (Clontech) were added to the mixture. The mixture was incubated at $42^{\circ} \mathrm{C}$ for $2 \mathrm{~h}$. The reaction was terminated by heating at $72^{\circ} \mathrm{C}$ for $15 \mathrm{~min}$. Obtained reaction mixture was used as first strand cDNA solution.

\section{Determination of nucleotide sequences of partial cDNA fragments for $L s C B F, L s G o l S 1$, and $L s G o l S 2$}

To determine sequence of $\mathrm{cDNA}$ of $L s C B F$, its partial fragments were obtained by using PCR with several primers (Table 1) and RACE fragments of each cDNA were obtained by using SMARTer RACE 5'/3' kit (Clontech) according to instructions' manual. Partial cDNA fragments of LsGolS1 and LsGolS2 were also obtained by using PCR with primers listed in Table 2. Then, sequencing of the obtained fragments was directly performed by a contractor (Macrogen Japan, Kyoto, Japan). Determined sequences were assembled for fur-

Table 1. Nucleotide sequences of the primers for amplification of partial fragments and determination of sequence of $L s C B F$

\begin{tabular}{lc}
\hline \multicolumn{1}{c}{ Primer name } & \multicolumn{1}{c}{ Sequence } \\
\hline LsCBF No.1 (F) & 5'-TCCGG(C/T)AAGTGGGT(C/T)TGTGA-3' \\
LsCBF No.2 (R) & 5'-GCCGC(C/T)TT(C/T)TG(A/G)ATGTCCTT-3' \\
LsCBF No.3 (F) & 5'-CCGGTAAGTGGGTTTGTGAG-3' \\
LsCBF No.4 (F) & 5'-TCAGCGTGTTTGAATTTTGC-3' \\
LsCBF No.5 (R) & 5'-GCCACACCCTCGTTTTCTTA-3' \\
LsCBF No.6 (F) & 5'-TGCCGGTCCCGGAATCTAGT-3' \\
LsCBF No.7 (R) & 5'-TTGCGTATCCATCAATCTGG-3' \\
LsCBF No.8 (F) & 5'-GGAAGAAGTTCAAGGAAACACG-3' \\
LsCBF No.9 (R) & 5'-CAATGGCACATTTGCGTATC-3' \\
3' CDS III primer (-T $\left.{ }_{30}\right)$ & 5'-ATTCTAGAGGCCGAGGCGGCCGACATG-3' \\
\hline
\end{tabular}


ther sequence analysis.

\section{Sequence analysis}

Sequence alignment and phylogenic analysis were performed using the Clustal W program (http://clustalw. ddbj.nig.ac.jp/index.php?lang=ja).

\section{PCR and semi-quantitative RT-PCR}

KOD Fx Neo DNA polymerase (Toyobo, Osaka, Japan) was used for PCR. Standard reaction was carried out according to the manufacturer's instruction. The PCR reaction was carried out with a $20 \mu \mathrm{l}$ mixture containing $0.2 \mathrm{U}$ of KOD Fx Neo DNA polymerase, $1 \times$ KOD Fx Neo buffer, $400 \mu \mathrm{M}$ dNTP, $20 \mathrm{pmol}$ of each appropriate primer (Tables 1 and 2), and $1 \mu \mathrm{l}$ of the reverse transcription (RT) reaction mixture. The mixtures were subjected to PCR amplification consisting of template DNA denaturation at $98^{\circ} \mathrm{C}$ for $10 \mathrm{~s}$, primer-template annealing at $55^{\circ} \mathrm{C}$ for $30 \mathrm{~s}$, and primer extension at $68^{\circ} \mathrm{C}$ for $30 \mathrm{~s}$. Total RNA or poly $(\mathrm{A})^{+} \mathrm{RNA}$ solutions were used in place of the $\mathrm{RT}$ reaction mixture in order to confirm the absence of genomic DNA in the RNA solution.

The relative levels of transcription were calculated by normalization of expression level of actin gene from lettuce (Accession number as mRNA, AY260165.1).

\section{qPCR}

qPCR was performed on Mx3000P ${ }^{\mathrm{TM}}$ Real-Time PCR System (Stratagene, La Jolla, CA, USA) with the SYBR Premix Ex Taq ${ }^{\mathrm{TM}}$ (Perfect Real Time) according to the manufacturer's instruction. Each reaction was carried out at least three times, with threshold cycle $\left(\mathrm{C}_{\mathrm{T}}\right)$ determined in duplicate. Used primers were shown in Table 2.

\section{Southern blot analysis}

Genomic DNA from lettuce was prepared using a DNeasy Plant Mini Kit (Qiagen Co. Ltd., Hilden, Germany). Ten micrograms of the genomic DNA was digested with EcoRI, fractionated on an agarose gel, and blotted onto a Hybond $\mathrm{N}^{+}$nylon membrane (GE healthcare, Heidenberg, Germany). The membrane was subjected to Southern blot analysis. For preparation of a DIG-labeled probe, a PCR DIG Probe Synthesis Kit (Roche, Basel, Switzerland) was used and PCR was car- ried out using LsCBF No. 3 and No. 7 primers and a partial fragment of LsCBF as a template. Then, the blotted membrane was incubated at $55^{\circ} \mathrm{C}$ in a DIG Easy $\mathrm{Hyb}$ solution (Roche), and the re-incubated in the same solution supplemented the DIG-labeled probe overnight. The membrane was washed with $2 \times$ SSC and $0.1 \%$ SDS at room temperature, followed by $0.1 \times$ SSC and $0.1 \%$ SDS at $68^{\circ} \mathrm{C}$. After washing, detection was carried out by using a DIG Nucleic Acid Detection Kit (Roche).

\section{Statistical analysis}

Statistical analysis was performed using Excel 2011 (Microsoft, USA) with the add-in software Satcel 2 (Yanai 2004).

\section{RESULTS AND DISCUSSION}

\section{Freezing tolerance of lettuce plants}

In order to study freezing tolerance of lettuce, three cultivars (Papa lettuce, Mama lettuce, and Berkley) were grown at $22^{\circ} \mathrm{C}$ for two weeks. Then, they were cold-treated at $2^{\circ} \mathrm{C}$ for indicated periods and moved into a freezer at $-3^{\circ} \mathrm{C}$. Freezing tolerance was evaluated with viability of lettuce plants which had been frozen at $-3^{\circ} \mathrm{C}$ for $24 \mathrm{~h}$ and then grown at $22^{\circ} \mathrm{C}$ for one week. Survival rates of lettuce plants, which had been cold-treated at $2^{\circ} \mathrm{C}$ for 4-7 days, were significantly enhanced compared to those of untreated plants (Figs. 1 and 2). Furthermore, viabilities of lettuce plants after freezing and thawing were increased with the length of cold treatment period. Berkley showed the highest viability among three cultivars cold-treated for 4 days, however, viabilities of Papa lettuce and Mama lettuce cultivars treated for 7 days were enhanced as same as that of Berkley cultivar treated for 7 days. So, any remarkable differences in freezing tolerance among three cultivars were not observed after 7 days. In further experiments, Papa lettuce cultivar was used for further experiments.

To our knowledge, there are no research papers regarding to acquisition of freezing tolerance of lettuce plants. In Japan, lettuce is cultivated at cool areas located in high altitude in summer and at areas located in low altitude in winter. Thus, lettuce is estimated to relatively be strong against non-freezing low tempera-

Table 2. Nucleotide sequences of the primers of the target genes for semi-quantitative RT-PCR or qPCR.

\begin{tabular}{|c|c|c|c|}
\hline $\begin{array}{l}\text { Gene } \\
\text { (Accession number) }\end{array}$ & Primer & Nucleotide sequence & $\begin{array}{l}\text { Ampricon } \\
\text { (bp) }\end{array}$ \\
\hline$L s C B F$ & LsCBF NO.7(F) & 5'-GGAAGAAGTTCAAGGAAACACG-3' & 530 \\
\hline (LC380915) & LsCBF No. 8(R) & 5'-CAATGGCACATTTGCGTATC-3' & \\
\hline LsGolS1 & LsGolS1C(F) & 5'-TTT ACC CAC CGG AAA GTC AG-3' & 185 \\
\hline (DY975888) & LsGolS1C(R) & 5'-GTC CAT CAC CGC GTA AAA GT-3' & \\
\hline LsGolS2 & LsGolS2C(F) & 5'-CCC AAT CTC TCC ACC TAC CA-3' & 201 \\
\hline (DY971098) & LsGolS2C(R) & 5'-GCA GTA GTG CAC CAC CTT GA-3' & \\
\hline LsActin & LsActin (F) & 5'-AAG CCC AAT CGA AAA GAG GT-3' & 199 \\
\hline (AY260165.1) & LsActin (R) & 5'-GCC TCT GTA AGG AGC ACA GG-3' & \\
\hline
\end{tabular}




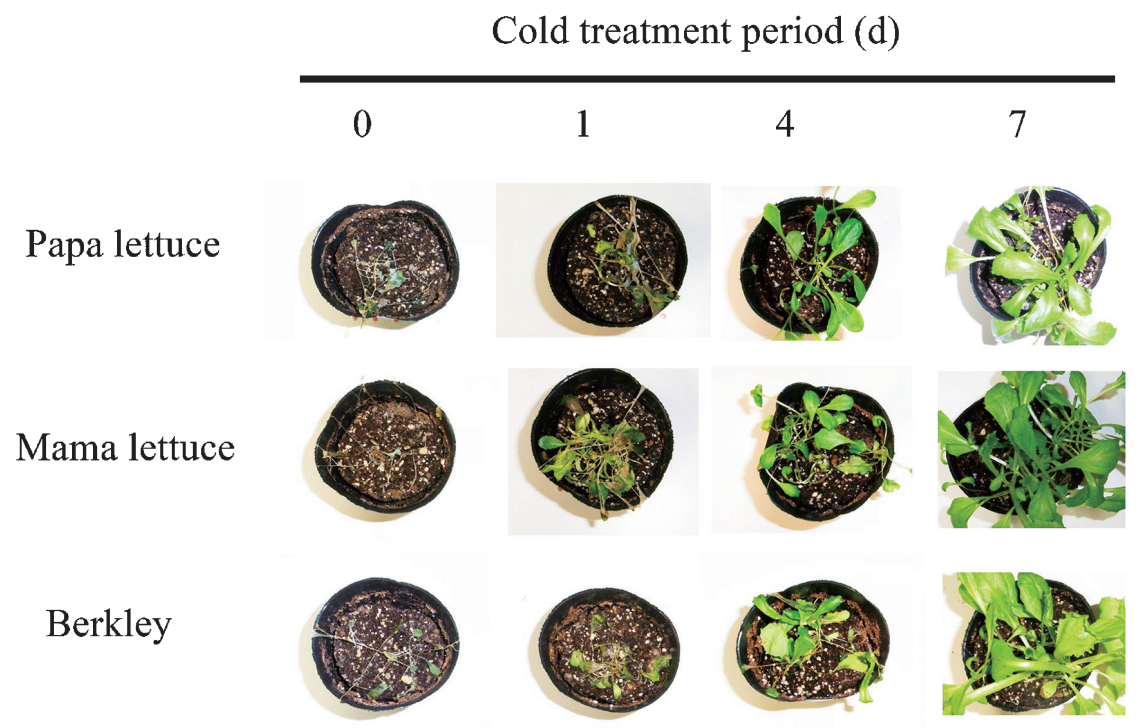

Fig. 5. Photos of lettuce plants after freezing-thawing. Lettuce plants were incubated at $2^{\circ} \mathrm{C}$ for indicated periods, frozen at $-3^{\circ} \mathrm{C}$ for $24 \mathrm{~h}$, thawed at $2^{\circ} \mathrm{C}$ for $24 \mathrm{~h}$, and then grown under normal cultivation conditions at $22^{\circ} \mathrm{C}$. Samples of 0 day were not incubated at $2^{\circ} \mathrm{C}$. The photos were taken one week after freezing-thawing. Representative pictures of the samples are shown here.

(A)

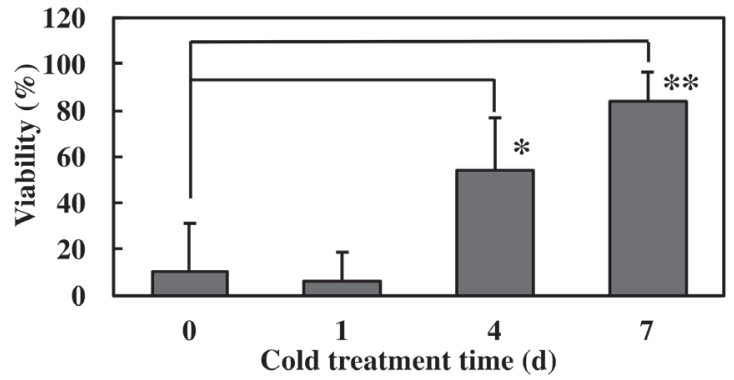

(B)

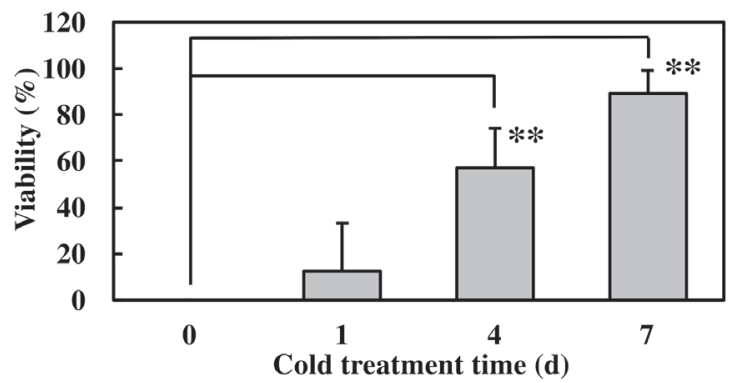

(C)

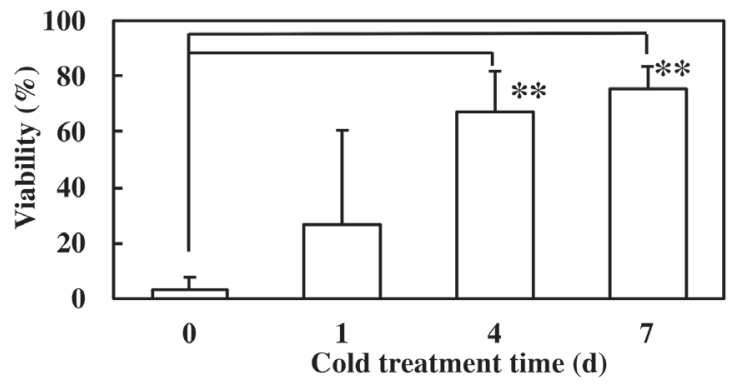

Fig. 2. Freezing tolerance of lettuce evaluated by viability. (A) Papa lettuce, (B) Mama lettuce and (C) Berkley. Values are means \pm S.D. Significance is indicated as: $* p<$ 0.05 or $* * p<0.01$. ture. Our results showed that cold treatment at $2^{\circ} \mathrm{C}$ improved freezing tolerance of lettuce at $-3^{\circ} \mathrm{C}$. This indicates a possibility that freezing tolerance of lettuce might be further improved by using any means such as transgenic approaches. Although lettuce is major produce, there is one report regarding improvement of freezing tolerance of lettuce by using transgenic technique. Vanjildorj et al. (2005) reported that transgenic lettuce with transcriptional factor $A B F 3$ gene enhanced cold tolerance of the lettuce plant at $-4^{\circ} \mathrm{C}$. Although detail mechanisms of the improvement of freezing tolerance were not mentioned in the paper, overexpression of the $A B F 3$ gene would lead to expression of $A B F 3-$ inducible genes in the lettuce plant. Thus, transgenic approach has a possibility that freezing tolerance of lettuce plants might be dramatically improved dependently on introduced genes.

Regarding to response of lettuce to abiotic stress such as salt stress, there are a few research papers of stress response of $L$. sativa using techniques of molecular biology except for a study on drought-induced expression of DREB2A gene, designated LsDREB2A, from $L$. sativa by Kudo et al. (2014). Park et al. (2005) also improved salt and drought tolerance of lettuce by constitutive expression of LEA with transgenic technique. DREB2A is a transcriptional factor regulating stressinducible genes and LEA probably work as a protectant against several stresses. Thus, utilization of transcriptional factors or stress tolerance plants would be helpful for enhancement of freezing tolerance.

\section{Cloning of a partial fragment of cDNA for LsCBF gene}

CBF(DREB1) and DREB2 are well known as ones of major stress responsive transcriptional factors (Mizoi $e t$ al., 2012). Although cDNA corresponding to LSDREB2A 

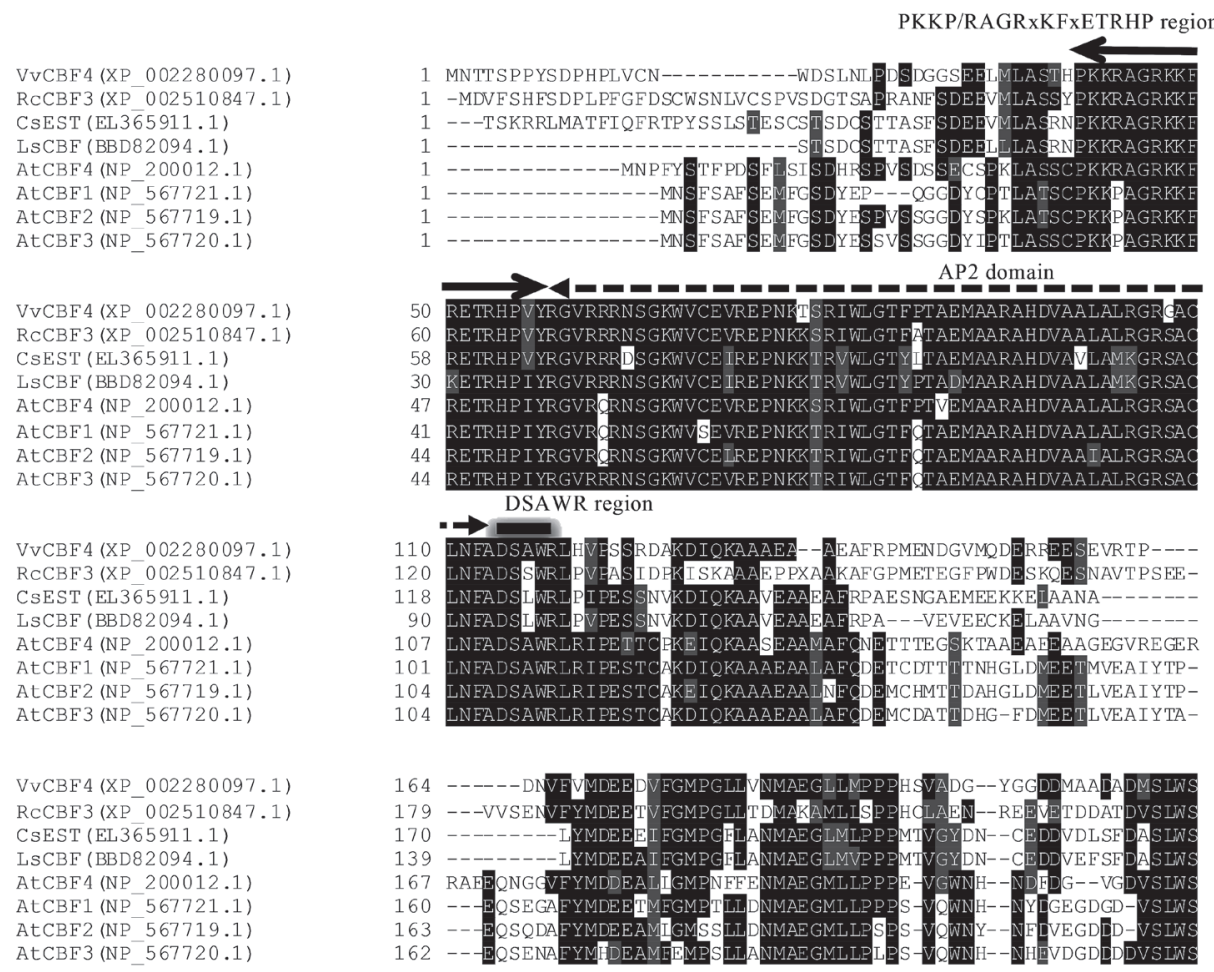

Fig. 3. Comparison of deduced amino acid sequence of partial fragment of $L s C B F$ with those of other CBF proteins.

Identical amino acid residues and relatively similar amino acid residues are shaded in black and grey colors, respectively. Dashes are no amino acids.

AP2 domains and other two conserved regions of CBF proteins, PKKP/RAGRxKFxETRHP and DSAWR regions, are also shown. Numbers in parenthesus are NCBI reference or GenBank accession numbers. Plants explained in abbreviations are as follows. At: Arabidopsis thaliana, Cs: Cichorium endivia, Ls: Lactuca sativa, Rc: Ricinus communis, Vv: Vitis vinifera.

was isolated from lettuce and studied by Kudo et al. (2014), another type such as $C B F(D R E B 1)$ had not been identified in lettuce so far. This means that expression pattern of $C B F$ gene during cold treatment of lettuce has not been investigated. At first, we designed degenerate primers for amplification of a partial fragment of cDNA corresponding to $C B F$ gene $(L s C B F)$ from lettuce (Table 1). Then, we carried out PCR by using cDNA derived from poly $(\mathrm{A})^{+} \mathrm{RNA}$ of papa lettuce. Nucleotide sequence of the obtained PCR fragment was determined. After obtaining a part of cDNA of $L s C B F$, RACE method and several degenerated primers were used for determination of sequence of cDNA of $L s C B F$. Although we could not obtain full-length sequence of cDNA for $L s C B F$, a partial fragment composing of 672 bp (DDBJ accession number, LC380915) was obtained and the fragment encoded 191 amino acids. The deduced amino acid sequence showed similarity to those of $\mathrm{CBF}$ proteins from other plant sources (Fig. 3). CBF transcriptional factor belongs to transcriptional factors of AP2 family (Jaglo et al., 2001). AP2 domain was found in the deduced amino acid sequence of the obtained fragment. Furthermore, PKKP/RAGRxKFxETRHP and DSAWR regions, which are specific to common of $\mathrm{CBF}$ proteins, were found in the sequence. Thus, the obtained fragment was confirmed to be a part of cDNA for $L s C B F$ gene. This result shows a possibility that lettuce has a

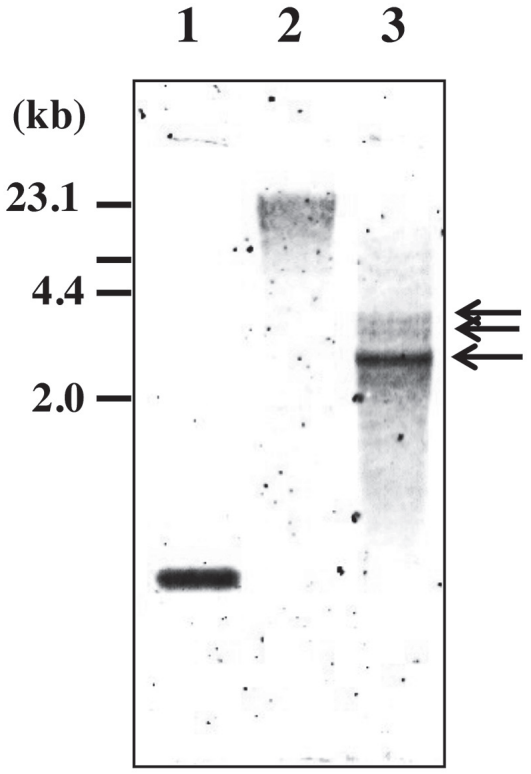

Fig. 4. Southern blot analyses of genomic DNA of lettuce. Lanes: 1, Positive control; 2, Intact lettuce genomic DNA; 3, EcoRI digested lettuce genomic DNA. PCR product of $L s C B F$ was used as a probe. 


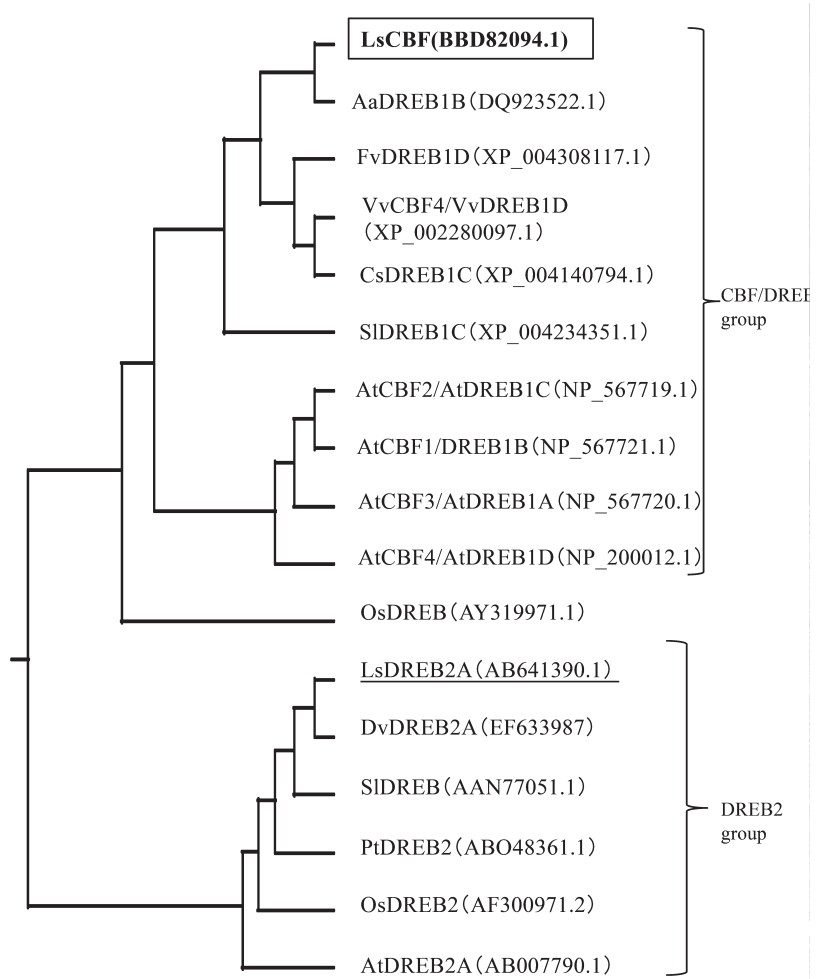

Fig. 5. Phylogenetic analysis using the Neighbor-Joining method and based on predicted amino acid sequences of confirmed or putative $\mathrm{CBF} / \mathrm{DREB} 1$ and DREB2 proteins from different plant species. Comparison sequences were Aa, Ageratina adenophora; At, Arabidopsis thaliana; Cs, Cucumis sativa; Dv, Dendranthema vestitium; Fv, Fragaria vesca; Os, Oryza sativa; Pt, Populus trichocarpa; Sl, Solanum lycopersicum; Vv, Vitis vinifera; Zm, Zea mays. Numbers in parenthesus are NCBI reference or GenBank accession numbers.

cold responsive pathway as same as other plants such as Arabidopsis thaliana which acquires freezing tolerance by exposure to cold.

Because there are over 10 homologs for $C B F$ in Arabidopsis, it was expected that there are several homologs for $L s C B F$ genes in the present study. Thus, by using a partial fragment of $L s C B F$ as a probe, we tried to perform genomic Southern blot hybridization (Fig. 4). At least one strongly-hybridized band and several weakly-hybridized bands were detected, suggesting existence of other $L s C B F$-like genes. At present, a $C B F$ homolog gene, LsDREB2A (accession number AB641390.1) was cloned from lettuce by another researcher (Kudo et al., 2014). We compared deduced amino acid sequence of the cloned $L s C B F$ to those of other $C B F$ homologs and made a phylogenetic tree of CBF proteins (Fig. 5). The results showed that LsCBF protein was categorized to DREB1 group and LsDREB2A protein was categorized to DREB2 group. DREB1 is major regulator of cold-response and DREB2 is regulator of heat and drought response (Mizoi et al., 2012). Thus, the corresponding gene to isolated cDNA was considered to be newly identified for cold regulation factor in the present paper.
(A)

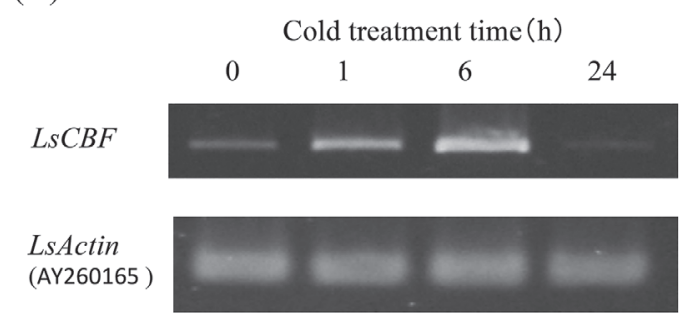

(B)

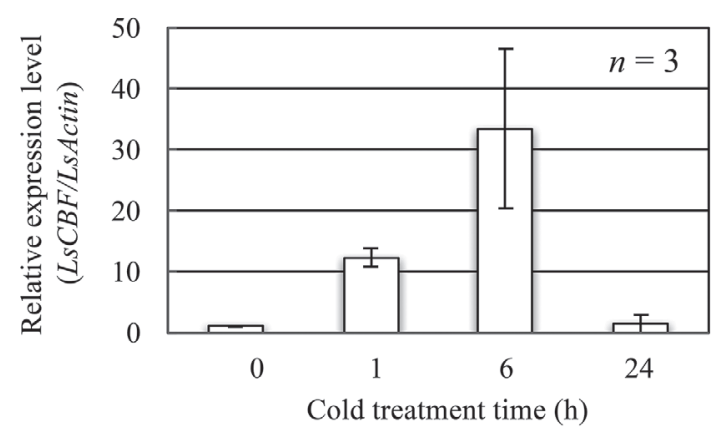

Fig. 6. Differential expression analysis of $C B F$ genes in lettuce under cold treatment.

Expression levels of $L s C B F$ were estimated by (A) semi-quantitative PCR and (B) quantitative RT-PCR. Total RNAs were extracted from leaves of plants treated with $2^{\circ} \mathrm{C}$ for $0,1,6$, and $24 \mathrm{~h}$, and subjected to respective measurement methods. Quantification of transcriptional levels for $L s C B F$ gene, compared with a control, was calculated after normalization to the actin gene of L. sativa.

\section{Response of LsCBF to cold treatment}

The expression pattern of $C B F$ gene was investigated by using semi-quantitative and real-time RT-PCR (Fig. 6), $C B F$ gene was remarkably induced at 1 and $6 \mathrm{~h}$ of cold treatment. However, at $24 \mathrm{~h}$ of cold treatment, its transcriptional level returned to the almost same level in non-cold treated lettuce plant. This suggests that lettuce has a signal pathway responding to cold as well as other plants which acquire freezing tolerance. Although expression of a $C B F$ gene in tomato plants is induced by cold treatment, the expression level of the gene, at $24 \mathrm{~h}$ of cold treatment, returned to the level in warm-grown plants (Jaglo et al., 2001). As well as freezing-sensitive plants such as tomato, even if $C B F$ gene from lettuce might be induced by cold once, the expression level of the gene appeared to be lowered soon. Furthermore, Jaglo et al. (2001) suggested that there were few cold-regulated genes responsive to CBF/DRE elements in tomato. Similarly, there might be fewer cold-regulated genes in lettuce than those in other freezing-tolerant plants.

Zhang et al. (2004) reported that tomato (Lycopersicon esculentum) has three homologues for $C B F$ gene (LeCBF1, LeCBF2, LeCBF3) and only $L e C B F 1$ gene was cold-inducible. They also confirmed that LeCBF1 functions in transgenic Arabidopsis as well as $A t C B F$ 3, leading to enhancement of freezing tolerance. However, overexpression of $L e C B F 1$ or $A t C B F 3$ 


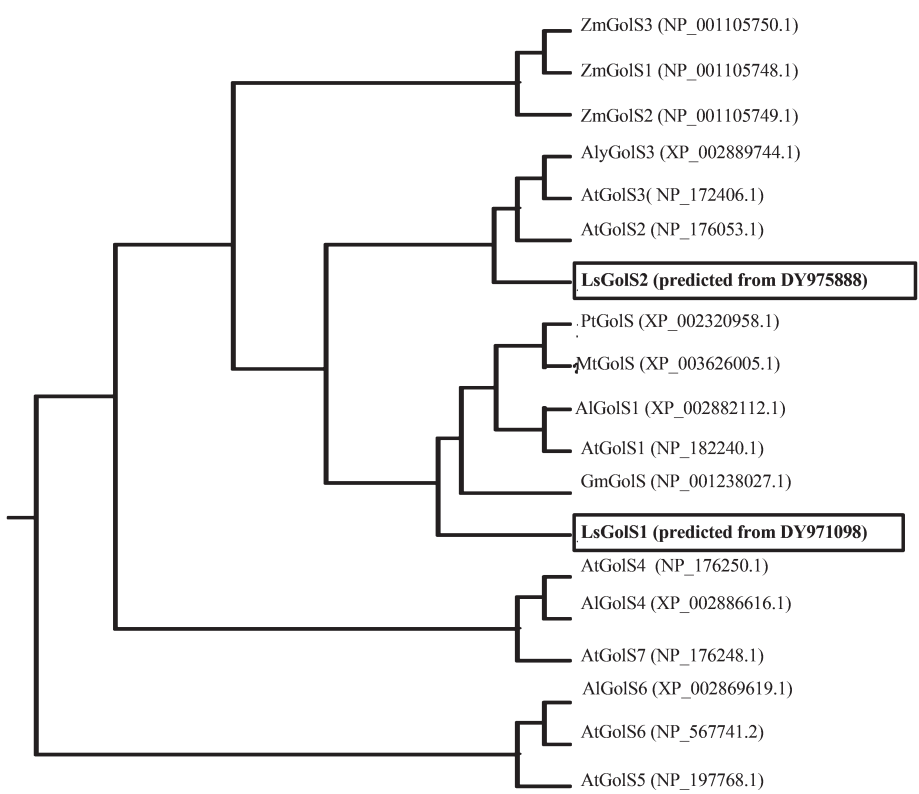

Fig. 7. Phylogenetic analysis using the Neighbor-Joining method and based on predicted amino acid sequences of confirmed or putative GolS proteins from different plant species. Comparison sequences were Al: Arabidopsis lyrata, At: Arabidopsis thaliana, Cs: Cichorium endivia, Gm: Glycine max, Mt: Medicago truncatula, Ls: Lactuca sativa, Pt: Populus trichocarpa, Rc: Ricinus communis, Vv: Vitis vinifera, Zm: Zea mays. Numbers in parenthesus are NCBI reference or GenBank accession numbers.

(A)

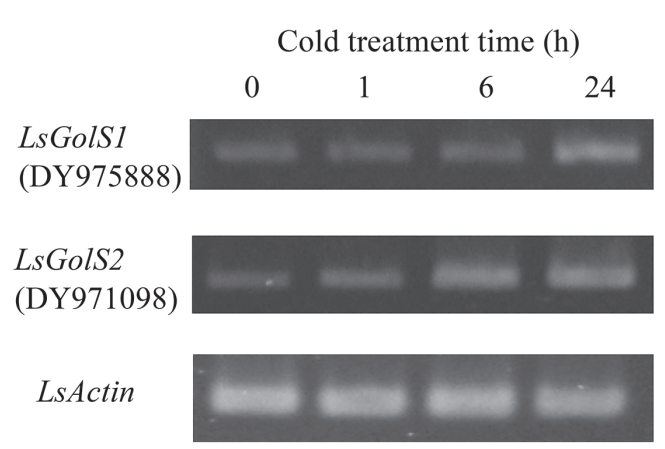

(B)
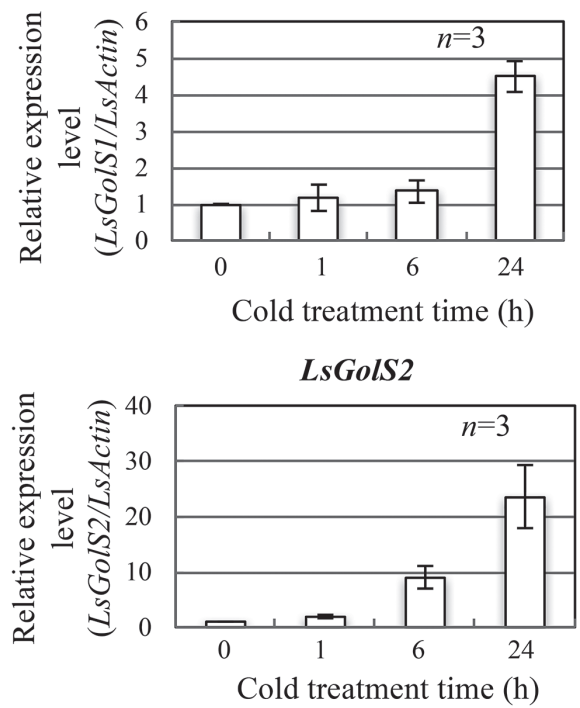

Fig. 8. Differential expression analysis of $L s G o l S 1$ and $L s G o l S 2$ genes in lettuce under cold treatment. Expression levels of LsGolS1 and LsGolS2 were estimated by(A) semi-quantitative PCR and (B) quantitative RT- PCR.

Total RNAs were extracted from leaves of plants treated with $2^{\circ} \mathrm{C}$ for $0,1,6$, and $24 \mathrm{~h}$, and subjected to respective measurement methods. Quantification of transcriptional levels for LsGolS1 and LsGolS2 genes, compared with a control, was calculated after normalization to the actin gene of $L$. sativa.

gene in transgenic tomato plants did not enhance freezing tolerance of the plants. Furthermore, by using microarray analysis, there were only four genes which were up-regulated by LeCBF1 or AtCBF3 (Zhang et al., 2004).
As described above, tomato is sensitive to freezing stress (Jaglo et al., 2001). In the present paper, it was confirmed that at least one $C B F 1$ gene homologue ( $L s C B F$ ) exists in lettuce (Fig. 4) and was up-regulated by cold 
(Fig. 3). However, similar case to that in tomato (Zhang et al., 2004) was anticipated. That is, even if CBF proteins are expressed in lettuce, freezing tolerance of the lettuce plant expressing the proteins might not be improved. The fact suggests that there might be only few genes which are up-regulated by $L s C B F$ in lettuce. Furthermore, it also suggests that even if expression level of $L s C B F$ in lettuce is enhanced, improvement of freezing tolerance of lettuce is not expected. Thus, we targeted another gene with functions leading to improvement of freezing tolerance.

\section{Cloning of partial fragments of cDNA for LsGolS genes and cold response of the genes}

GolS is a key enzyme for raffinose synthesis and catalyzes synthesis of galactinol using UDP-galactose and myo-inositol as substrates (Taji et al., 2002). One of the corresponding genes is known as cold responsive genes (Zhuo et al., 2013). Thus, we started to analyze GolS genes in lettuce. By searching lettuce EST database, two candidates of EST for GolS genes were found and GenBank accession numbers of the candidate ESTs were DY975888 and DY971098. Deduced amino acid sequences were determined from nucleotide sequences of respective EST clones. The two EST clones were estimated to be derived from genes encoding GolS proteins and the corresponding genes were designated LsGolS1 and LsGolS2. The deduced amino acid sequences of LsGolS1 and LsGolS2 showed high similarity to those of GolS gene from other higher plants and phylogenic tree was constructed (Fig. 7).

By using Primer3 (http://primer3.ut.ee), primers for GolS genes were designed for analysis with semi-quantitative and qPCR. As expected based on the sequences, about 180-bp and 200-bp PCR products were amplified (data not shown). Nucleotide sequences of the products were determined and the amplified products were confirmed as parts of LsGolS1 and LsGolS2 genes, respectively. Then, semi-quantitative RT-PCR and qPCR were done for analysis of expression levels of respective $L s G o l S$ genes during cold treatment (Fig. 8). The results showed that the expression of both the genes were induced by cold. As well as GolS genes from other plants (Liu et al., 1998; Taji et al., 2002; Phan et al., 2009), $L s G o l S$ genes were confirmed to be induced by cold. LsGolS1 was induced at $24 \mathrm{~h}$ and LsGolS2 was induced at $6-\mathrm{h}$ cold treatment. Expression level of LsGolS2 seemed higher than that of LsGolS1.

As shown in Fig. 2, freezing tolerance of lettuce at $-3^{\circ} \mathrm{C}$ was enhanced. The level of the freezing tolerance might be enough to overcome frost damage at around $-3^{\circ} \mathrm{C}$ during cultivation period, however, it is not so high compared to those of other frost hardy plants such as spinach and Arabidopsis that acquire freezing tolerance at around $-10^{\circ} \mathrm{C}$ (Guy et al., 1985; Gilmour et al., 1991). Overexpression of galactinol synthase in transgenic plants improved tolerance of oxidative stress, salinity and osmotic stress, chilling stress, or freezing stress (Nishizawa et al., 2008; Sun et al., 2013; Shimosaka and Ozawa, 2015; Zhuo et al., 2012). Thus, by using trans- genic approach, constitutive expression of GolS has a possibility to further improve freezing tolerance of lettuce at lower temperatures.

In the present paper, we showed that lettuce has a cold response pathway, suggesting a possibility to improve freezing tolerance by using gene manipulation.

\section{ACKNOWLEDGEMENTS}

This study was financially supported by The SKYLARK Food Science Institute.

\section{REFERENCES}

Garrido, Y., J. A. Tudela, A. Marin, T. Mestre, V. Martinez and M. Gi 2013 Physiological, phytochemical and structural changes of multi-leaf lettuce caused by salt stress. J. Sci. Food. Agric., 94: 1592-1599

Gilmour, S. J., A. M. Sebolt, M. P. Salazar, J. D. Everard and M. F. Thomashow 2000 Overexpression of the Arabidopsis CBF3 transcriptional activator mimics multiple biochemical changes associated with cold acclimation. Plant Physiol., 124: 18541865

Gilmour, S. J. and M. F. Thomashow 1991 Cold acclimation and cold-regulated gene expression in ABA mutants of Arabidopsis thaliana. Plant Mol. Biol., 17: 1233-1240

Guy, C. L., K. J. Niemi and R. Brambl 1985 Altered gene expression during cold acclimation of spinach. Proc. Natl. Acad. Sci. USA, 82: 3673-3677

Jaglo, K. R., S. Kleff, K. L. Amundsen, X. Zhang, V. Haake, J. Z. Zhang, T. Deits and M. F. Thomashow 2001 Components of the Arabidopsis C-repeat/dehydration responsive element binding factor cold-response pathway are conserved in Brassica napus and other plant species. Plant Physiol., 127: 910-917

Kudo, K., T. Oi, and Y. Uno 2014 Functional characterization and expression profiling of a DREB2-type gene from lettuce (Lactuca sativaL.). Plant Cell Tissue Org. Cult., 116: 97-109

Leyva, R., E. Sánchez-Rodríguez, J. J. Ríos, M. M. Rubio-Wilhelmi, L. Romero, J. M. Ruiz and B. Blasco 2011 Beneficial effects of exogenous iodine in lettuce plants subjected to salinity stress. Plant Sci., 181: 195-202

Liu, J.-J., D. C. Krenz, A. F. Galvez, and B. O. de Lumen 1998 Galactinol synthase (GS): increased enzyme activity and levels of mRNA due to cold and desiccation. Plant Sci., 134: 11-20

Mizoi, J., K. Shinozaki and K. Yamaguchi-Shinozaki 2012 AP2/ ERF family transcription factors in plant abiotic stress responses. Biochim. Biophys. Acta-Gene Regul. Mech., 1819: 86-96

Nicolle, C., N. Cardinault, E. Gueux, L. Jaffrelo, E. Rock, A. Mazur, P. Amouroux and C. Rémésy 2004 Health effect of vegetablebased diet: lettuce consumption improves cholesterol metabolism and antioxidant status in the rat. Clin. Nutr., 23: 605-614

Phan, T., Y. Ishibashi, T. Yuasa and M. Iwaya-Inoue 2009 Chilling stress induces galactinol synthase (OsGolS1) in rice seedling. Cryobiol. Cryotechnol., 55: 139-146

Porcel, R., R. Azcón and J.M. Ruiz-Lozano 2005 Evaluation of the role of genes encoding for dehydrin proteins (LEA D-11) during drought stress in arbuscular mycorrhizal Glycine max and Lactuca sativa plants. J. Exp. Bot., 56: 1933-1942.

Ruiz-Lozano, J. M., R. Azcón and J. M. Palma 1996 Superoxide dismutase activity in arbuscular mycorrhizal Lactuca sativa plnants subjected to drought stress. New Phytol., 134: 327-333

Shimosaka, E. and K. Ozawa 2015 Overexpression of cold-inducible wheat galactinol synthase confers tolerance to chilling stress in transgenic rice. Breed. Sci., 65: 363-371

Stockinger, E. J., S. J. Gilmour and M. F. Thomashow 1997 Arabidopsis thaliana CBF1 encodes an AP2 domain-containing transcriptional activator that binds to the C-repeat/DRE, a cis-acting DNA regulatory element that stimulates transcription in response to low temperature and water deficit. Proc Natl 
Acad Sci USA, 94: 1035-1040

Sun, Z., Q. W. Qi, Z. Wang, P. Li, C. Wu, H. Zhang and Y. Zhao 2013 Overexpression of TsGOLS2, a galactinol synthase, in Arabidopsis thaliana enhances tolerance to high salinity and osmotic stresses. Plant Phsiol. Biochem., 69: 82-89

Vanjildorj, E., T.-W. Bae, K.-Z. Riu, S.-Y. Kim and H.-Y. Lee 2005 Overexpression of Arabidopsis $A B F 3$ gene enhances tolerance to drought and cold in transgenic lettuce (Lactuca sativa). Plant Cell Tissue Org. Cult., 83: 41-50

Yanai, H. 2004 Statcel-the useful add-in software forms on Excel, 2nd edn. OMS, Tokyo

Zdravković, J. M., G. S. Aćamović-Djoković, J. D. Mladenović, R. M. Pavlović and M. S. Zdravković 2014 Antioxidant capacity and contents of phenols, ascoribic acid, $\beta$-carotene and lycopene in lettuce. Hem. Ind., 68: 193-198

Zhang, X., S. G. Fowler, H. Cheng, Y. Lou, S. Y. Rhee, E. J. Stockinger and M. F. Thomashow 2004 Freezing-sensitive tomato has a functional $\mathrm{CBF}$ cold response pathway, but a CBF regulon that differs from that of freezing-tolerant Arabidopsis, Plant J., 39: 905-919

Zhuo, C., T. Wang, S. Lu, Y. Zhao, X. Li and Z. Guo 2013 A cold responsive galactinol synthase gene from Medicago falcate (MfGolS1) is induced by myo-inositol and confers multiple tolerances to abiotic stresses. Physiol. Plant., 149: 67-78

Zuther, E., K. Büchel, M. Hundertmark, M. Stitt, D.K. Hincha and A. G. Heyer 2004 The role of raffinose in the cold acclimation response of Arabidopsis thaliana. FEBS Lett., 576: 169-173 